\title{
IMPLEMENTASI MODEL PEMBELAJARAN PROBLEM BASED LEARNING DALAM PEMBELAJARAN MATA KULIAH PENDIDIKAN KEWARGANEGARAAN UNTUK MENINGKATKAN INTELLECTUAL SKILLS MAHASISWA
}

\author{
${ }^{1}$ Erwin Susanto \\ ${ }^{1}$ Dosen Pendidikan Pancasila dan Kewarganegaraan \\ Fakultas Keguruan dan Ilmu Pendidikan \\ Universitas Buana Perjuangan Karawang \\ email: susanto@ubpkarawang.ac.id
}

\begin{abstract}
This study aims to see how the implementation of problem-based learning model in the course of civic education learning can improve students' intellectual skills. The approach used in this research is descriptive qualitative approach. This research was conducted on the Pancasila and Civic Education Program, Buana Perjuangan Karawang University. The result of this research is significantly, the application of Problem Based Learning model in the course of Citizenship Education is able to increase the intellectual skills of the students.
\end{abstract}

Keywords: Problem Based Learning, Intellectual Skills, Civic Education

\begin{abstract}
ABSTRAK
Penelitian ini bertujuan untuk melihat bagaimana implementasi model pembelajaran problem based learning dalam pembelajaran mata kuliah Pendidikan Kewarganegaraan dapat meningkatkan intellectual skills mahasiswa. Pendekatan yang digunakan dalam penelitian ini adalah pendekatan kualitatif deskriptif. Penelitian ini dilakukan pada perkuliahan Pendidikan Kewarganegaraan Program Studi Pendidikan Pancasila dan Kewarganegaraan, Universitas Buana Perjuangan Karawang. Hasil dari penelitian ini adalah secara signifikan, penerapan model pembelajaran Problem Based Learning pada mata kuliah Pendidikan Kewarganegaraan mampu meningkatkan intellectual skills mahasiswa.

Kata Kunci: Model Pembelajaran Problem Based Learning, Intellectual skills, PPKn
\end{abstract}

\section{PENDAHULUAN}

Pembelajaran yang akan selalu diingat oleh manusia ialah pembelajaran yang didasari oleh problematika yang dialaminya dalam kehidupan sehari-hari. Dalam pembelajaran berbasis masalah, masalah yang nyata dan kompleks memotivasi mahasiswa untuk mengidentifikasi dan meneliti konsep dan prinsip yang mereka perlu ketahui untuk berkembang melalui masalah tersebut. Mahasiswa bekerja dalam tim kecil, dan memperoleh, mengomunikasikan,

serta memadukan informasi dalam proses yang menyerupai atau mirip dengan menemukan (inquiry).

Boud dan Felleti (1997:28) menyatakan bahwa "Problem Based Learning is a way of constructing and teaching course using problem as a stimulus and focus on student activity". H.S. Barrows (1982) menyatakan bahwa Problem Based Learning adalah sebuah metode pembelajaran yang didasarkan pada prinsip bahwa masalah (problem) 
dapat digunakan sebagai titik awal untuk mendapatkan atau mengintegrasikan pengetahuan (knowledge) baru. Sehingga masalah tersebut dijadikan sebagai sarana agar mahasiswa dapat belajar yang dapat menunjang keilmuan yang ditekuninya.

Problem Based Learning dapat dikatakan sebagai pembelajaran yang titik awal pembelajaran didasarkan pada masalah dalam kehidupan nyata, kemudian dari masalah tersebut mahasiswa diberi rangsang untuk mempelajari masalah dengan menggunakan pengetahuan dan pengalaman yang telah mereka dapatkan sbelumnya, sehingga nantinya pengetahuan dan pengalaman lama mereka akan membentuk pengetahuan dan pengalaman yang baru. Hal tersebut jika dikaitkan dengan permasalahan kehidupan kewarganegaraan di Indonesia, maka kecerdasan berpikir untuk memecahkan masalah-masalah yang ada akan dibutuhkan bagi mahasiswa. Komponen kecerdasan berpikir inilah yang akan menjadi perwujudan warganegara yang cerdas.

Berdasarkan permasalahan yang telah disebutkan di atas, peneliti tertarik untuk meneliti lebih jauh mengenai penerapan model pembelajaran Problem Based Learning dalam pembelajaran mata kuliah Pendidikan Kewarganegaraan untuk meningkatkan intellectual skills mahasiswa.

\section{Rumusan Masalah}

Berdasarkan latar belakang penelitian, maka rumusan masalah dalam penelitian ini yaitu "bagaimanakah implementasi model pembelajaran problem based learning pada mata kuliah Pendidikan Kewarganegaraan dapat meningkatkan intellectual skills mahasiswa?"

\section{Tujuan Penelitian}

Penelitian ini bertujuan untuk mendeskripsikan dan menganalisis secara mendalam mengenai perencanaan, pelaksanaan dan hasil dari implementasi model pembelajaran problem based learning pada mata kuliah Pendidikan Kewarganegaraan yang dapat meningkatkan intellectual skills mahasiswa.

\section{METODE PENELITIAN}

Pada dasarnya, menyelesaikan masalah dalam penelitian perlu adanya metode dan suatu pendekatan penelitian. Pendekatan yang digunakan dalam penelitian ini adalah pendekatan kualitatif. Seperti yang dikemukakan oleh Nasution (2003:5), bahwa hakikat penelitian kualitatif adalah "untuk mengamati orang dalam lingkungan hidupnya, berinteraksi dengan mereka, berusaha memahami bahasa dan tafsiran mereka tentang dunia sekitar".

Adapun alasan penggunaan pendekatan ini adalah karena ia mampu lebih mendekati peneliti dengan objek yang dikaji, sebab peneliti langsung mengamati objek yang dikaji dengan kata lain peneliti bertindak sebagai alat utama riset (human instrumen).

Menurut Creswell (1998: 147150) menyebutkan langkah-langkah yang sering dipakai dalam penelitian kualitatif adalah sebagai berikut:

a. Peneliti memulai dengan suatu deskripsi penuh mengenai mengalaman pribadinya tentang fenomena tersebut.

b. Peneliti kemudian menemukan pernyataanpernyataan, tentang bagaimana orang memahami 
topic yang diteliti, membuat daftar pertanyaan yang signifikan dan memperlakukan semua data secara sama.

c. Pertanyaan-pertanyaan ini kemudian dikelompokkan ke dalam unut-unit makna, peneliti membuat daftar unit-unit dan kemudian menulis sebuah deskripsi.

d. Peneliti kemudian melakukan refleksi pada deskripsi pribadinya dan menggunakan variasi imajinatif atau deskripsi structural, mencari semua makna.

e. Peneliti kemudian menyusun suatu deskripsi menyeluruh dari makna dan esensi dari pengalaman tersebut.

Maka dari itu, peneliti ingin mengetahui bagaimana implementasi model pembelajaran problem based learning pada mata kuliah pendidikan kewarganegaraan di Prodi PPKn UBP Karawang,. Sehingga peneliti memperoleh gambaran dari permasalahan yang terjadi secara mendalam (berupa kata-kata, gambar, prilaku) dan tidak dituangkan dalam bentuk bilangan atau angka statistik, melainkan tetap dalam bentuk kualitatif.

Selain itu, metode penelitian yang digunakan dalam penelitian ini adalah metode deskriptif. Dalam penelitian tersebut berusaha menggambarkan peristiwa dan kejadian yang menjadi pusat perhatian penelitian ini. Adapun pengertian metode deskriptif menurut Sudjana dan Ibrahim (1989:64) yaitu: Pengertian deskriptif adalah penelitian yang berusaha mendeskripsikan suatu gejala, peristiwa, kejadian yang terjadi pada saat sekarang dengan perkataan lain, penelitian deskriptif mengambil masalah atau memusatkan perhatian kepada masalah-masalah aktual sebagaimana adanya pada saat penelitian dilaksanakan.

Berdasarkan dari penjelasan di atas jelas bahwa mengenai penelitian implementasi model pembelajaran problem based learning pada mata kuliah pendidikan kewarganegaraan, merupakan suatu hal yang terjadi pada saat sekarang di lingkungan kelas mata kuliah PKn di Prodi PPKn dengan melihat faktafakta yang ada dalam lingkungan tersebut. Jadi hasil analisis dari penelitian tersebut berupa pemaparan gambaran mengenai situasi objek yang diteliti dalam bentuk uraian naratif.

\section{HASIL PENELITIAN}

Hasil yang didapatkan dari penelitian ini adalah sebagai berikut:

\section{Tahap Persiapan Implementasi Model Pembelajaran PBL}

Pada tahap ini, dosen pengampu Mata Kuliah Pendidikan Kewarganegaraan mempersiapkan kelengkapan pembelajaran yang diperlukan untuk mengimplementasikan model pembelajaran Problem Based Learning. Pertama dosen memilih masalah apa yang sedang hangat terjadi dan cocok dengan materi yang akan disampaikan kepada mahasiswa. Dalam penelitian ini, materi yang akan disampaikan oleh dosen PKn adalah Identitas Nasional dengan mengangkat masalah mengenai kelompok-kelompok yang ingin mengganti identitas nasional Indonesia. 


\section{Tahap Pelaksanaan \\ Implementasi Model \\ Pembelajaran PBL}

Pada pelaksanaannya, dosen mempunyai peran penting dalam suksesnya implementasi model pembelajaran Problem Based Learning, diantaranya yang dilakukan dosen selama perkuliahan berlangsung adalah sebagai berikut:

Tabel 1 Proses Pelaksanaan PBL

\begin{tabular}{|c|c|c|}
\hline $\begin{array}{l}\mathbf{N} \\
\mathbf{0}\end{array}$ & $\begin{array}{l}\text { Nama } \\
\text { Langkah }\end{array}$ & $\begin{array}{l}\text { Deskripsi } \\
\text { Tugas }\end{array}$ \\
\hline 1 & $\begin{array}{l}\text { Mengorientas } \\
\text { i mahasiswa } \\
\text { pada masalah }\end{array}$ & $\begin{array}{l}\text { Dosen } \\
\text { menjelaska } \\
\mathrm{n} \text { tujuan } \\
\text { pembelajar } \\
\text { an, bahan- } \\
\text { bahan yang } \\
\text { diperlukan, } \\
\text { memotivas } \\
\text { i } \\
\text { mahasiswa } \\
\text { terlibat } \\
\text { aktif pada } \\
\text { aktifitas } \\
\text { pemecahan } \\
\text { masalah } \\
\text { yang } \\
\text { dipilih }\end{array}$ \\
\hline 2 & $\begin{array}{l}\text { Mengorganis } \\
\text { asikan } \\
\text { mahasiswa } \\
\text { untuk belajar }\end{array}$ & $\begin{array}{l}\text { Dosen } \\
\text { membantu } \\
\text { mahasiswa } \\
\text { membatasi } \\
\text { dan } \\
\text { mengorgan } \\
\text { isasi tugas } \\
\text { belajar } \\
\text { yang } \\
\text { berhubung } \\
\text { an dengan } \\
\text { masalah } \\
\text { yang } \\
\text { dihadapi }\end{array}$ \\
\hline
\end{tabular}

\begin{tabular}{|c|c|c|}
\hline 3 & $\begin{array}{l}\text { Membimbing } \\
\text { penyelidikan } \\
\text { individu } \\
\text { maupun } \\
\text { kelompok }\end{array}$ & $\begin{array}{l}\text { Dosen } \\
\text { mendorong } \\
\text { mahasiswa } \\
\text { mengumpu } \\
\text { lkan } \\
\text { informasi } \\
\text { yang yang } \\
\text { dibutuhkan } \\
\text {, melaksana } \\
\text { kan } \\
\text { eksperime } \\
\text { n, dan } \\
\text { mencari } \\
\text { untuk } \\
\text { penjelasan } \\
\text { dan } \\
\text { pemecahan }\end{array}$ \\
\hline 4 & $\begin{array}{l}\text { Mengembang } \\
\text { kan dan } \\
\text { menyajikan } \\
\text { hasil karya }\end{array}$ & $\begin{array}{l}\text { Dosen } \\
\text { membantu } \\
\text { mahasiswa } \\
\text { merencana } \\
\text { kan dan } \\
\text { menyiapka } \\
\text { n karya } \\
\text { yang sesuai } \\
\text { seperti } \\
\text { laporan, } \\
\text { video, dan } \\
\text { model, dan } \\
\text { membantu } \\
\text { mereka } \\
\text { berbagi } \\
\text { tugas } \\
\text { dengan } \\
\text { temannya }\end{array}$ \\
\hline 5 & $\begin{array}{l}\text { Menganalisis } \\
\text { dan } \\
\text { mengevaluasi } \\
\text { proses } \\
\text { pemecahan } \\
\text { masalah }\end{array}$ & $\begin{array}{l}\text { Dosen } \\
\text { membantu } \\
\text { mahasiswa } \\
\text { melakukan } \\
\text { refleksi } \\
\text { terhadap } \\
\text { penyelidik } \\
\text { an dan } \\
\text { proses- }\end{array}$ \\
\hline
\end{tabular}




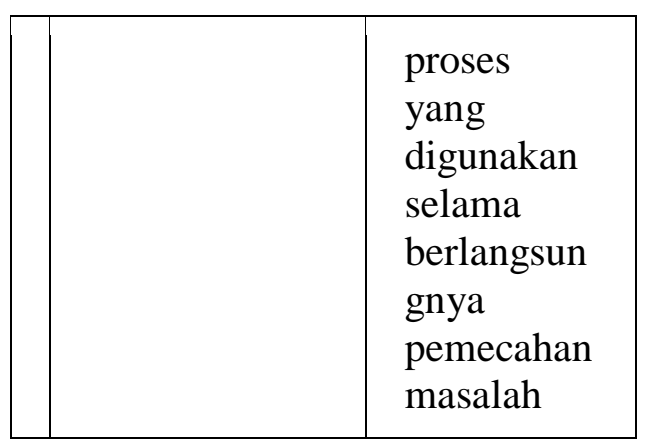

Sumber: Penulis, 2017

\section{Hasil Implementasi Model Pembelajaran PBL}

Setelah

dilakukan implementasi model pembelajaran PBL, hasil belajar yang diperoleh adalah mahasiswa terlibat aktif pada masalah yang telah dipilih untuk materi identitas nasional, mahasiswa mampu mengorganisasikan tugas belajar sesuai dengan masalah yang dihadapi, mahasiswa dapat mencari dan mengumpulkan informasi yang dibutuhkan untuk melakukan eksperimen dan mampu memecahkan masalah serta secara aktif mampu merefleksikan hasil dari proses pembelajaran terhadap kehidupan nyata.

\section{SIMPULAN}

Setelah dilakukan penelitian, maka dapat disimpulkan bahwa implementasi model pembelajaran problem based learning dapat meningkatkan intellectual skills mahasiswa. Hal tersebut dapat dilihat dari keaktifan mahasiswa berpartisipasi dalam proses pembelajaran seperti mengajukan pertanyaan dari informasi yang diberikan oleh dosen, menanggapi dan menjawab pertanyaan dengan menggunakan data dan informasi yang aktual dan faktual. Tidak hanya itu, mahasiswa mampu untuk mengorganisasikan tugas sesuai dengan masalah yang sedang dikaji dan mampu untuk merefleksikan hasil-hasil dari proses pembelajaran ke dalam kehidupan hanya para mahasiswa.

\section{DAFTAR REFERENSI}

Boud, D. \& Felleti, G.I. (1997). The challenge of problem based learning. London: Kogapage.

Branson, M.S. (1998). The role of civic education. Calabasas: Center For Civic Education.

Creswell, John. W. (1998). Qualitative inquiry and research design, choosing among five tradition. California: Sage Publication.

Dutch, Barbara J., Allen, Deborah E., and White, Harold B. (2000). Problem-Based Learning: Preparing Students to Succeed in the 21st Century.[Online]. Tersedia http://www.hku.hk/caut/homep age/tdg/5/TeachingMatter/Dec. 98.pdf

Hamalik. (2006). Proses Belajar Mengajar. Bandung: Bumi Aksara

Nasution. (2003). Metode Research (Penelitian Ilmiah). Jakarta: PT. Bumi Aksara

Roh, Kyeong Ha. (2003). ProblemBased Learning in Mathematics. Dalam ERIC Digest. ERIC Identifier: EDOSE-03-07. [Online]. Tersedia: http://www.ericdigest.org/

Sagala, Syaiful. (2009). Konsep dan makna pembelajaran. Bandung: CV. Alfabeta

Sudjana \& Ibrahim. (1989). Desain dan Analisis Eksperimen. Bandung: Tarsito

Tan, Oon-Seng. (2004). Cognition, Metacognition, and ProblemBased Learning, in Enhancing Thinking through Problembased Learning Approaches. Singapore: Thomson Learning 
UU RI. (2003). Undang-undang

Republik Indonesia No. 20 tahun 2003; sistem pendidikan nasional. 